\title{
Effect of anti-reflux therapy on pulmonary function in idiopathic pulmonary fibrosis: a systematic review and meta-analysis
}

\author{
Mei Yang ${ }^{1 \#}$, Jiajia Dong ${ }^{1 \#}$, Jing An ${ }^{1 \#}$, Lin Liu $^{2}$, Lei Chen ${ }^{1 \wedge}$ \\ ${ }^{1}$ Department of Respiratory and Critical Care Medicine, West China Hospital, West China School of Medicine, Sichuan University, Chengdu, \\ China; ${ }^{2}$ Department of Respiratory and Critical Care Medicine, 363 Hospital, Chengdu, China \\ Contributions: (I) Conception and design: L Chen, L Liu; (II) Administrative support: L Liu; (III) Provision of study materials or patients: M Yang, \\ J Dong, J An; (IV) Collection and assembly of data: M Yang, J An, J Dong; (V) Data analysis and interpretation: M Yang, L Chen, L Liu; (VI) \\ Manuscript writing: All authors; (VII) Final approval of manuscript: All authors. \\ \#These authors contributed equally to this work. \\ Correspondence to: Lei Chen. Department of Respiratory and Critical Care Medicine, West China Hospital, West China School of Medicine, Sichuan \\ University, Chengdu 610041, China. Email: lchens@126.com; Lin Liu. Department of Respiratory and Critical Care Medicine, 363 Hospital, \\ Chengdu 610041, China. Email: 1liniu@126.com.
}

\begin{abstract}
Background: Current guideline conditionally recommends regular use of anti-reflux medication in idiopathic pulmonary fibrosis (IPF). However, the effect of anti-reflux therapy in this group remains controversial. We systematically reviewed literatures to evaluate whether anti-reflux therapy could ameliorate pulmonary function in IPF.

Methods: We performed electronic search in PubMed, Embase and CENTRAL (Cochrane Central Register of Controlled Trials) to identify original articles published in English language. We included randomized controlled trials (RCTs) and observational studies regarding anti-reflux therapy on pulmonary function in IPF. Qualitative and quantitative analyses were conducted. In quantitative analysis, the inversevariance method with fixed-effect model was used to analyze pooled data.

Results: Fifteen studies (2 RCTs and 13 observational studies) including 3,891 patients with IPF were included. Pooled analysis suggested that anti-reflux therapy did not improve forced vital capacity (FVC)\% predicted [mean difference $(\mathrm{MD})=0.88,95 \%$ confidence interval $(\mathrm{CI}):-0.22$ to $1.98, \mathrm{P}=0.12, \mathrm{I}^{2}=0 \%, 8$ studies, $\mathrm{n}=3,076$ ], diffusing capacity of the lung for carbon monoxide (DLCO) \% predicted (MD =0.75, 95\% CI: -0.13 to $1.62, \mathrm{P}=0.10, \mathrm{I}^{2}=0 \%, 8$ studies, $\mathrm{n}=3,073$ ), and FVC decline (MD $=0.02,95 \% \mathrm{CI}:-0.01$ to 0.04 , $\mathrm{P}=0.29, \mathrm{I}^{2}=17 \%, 5$ studies, $\left.\mathrm{n}=1,586\right)$ in IPF.
\end{abstract}

Discussion: Anti-reflux therapy may not ameliorate pulmonary function in IPF. However, adequately powered studies are warranted to validate the present findings.

Keywords: Anti-reflux therapy; idiopathic pulmonary fibrosis; pulmonary function

Submitted May 03, 2021. Accepted for publication Aug 26, 2021.

doi: $10.21037 /$ jtd-21-771

View this article at: https://dx.doi.org/10.21037/jtd-21-771

^ ORCID: Mei Yang, 0000-0002-9349-9183; Lei Chen, 0000-0003-3476-0035. 


\section{Introduction}

Idiopathic pulmonary fibrosis (IPF) is a chronic, progressive fibrotic lung disease, characterized by unknown cause, progressive worsening of dyspnea and lung function, as well as high mortality (1-4). The pathogenetic mechanisms of IPF has been generally regarded as repetitive micro-injuries and aberrant repair of alveolar epithelium, which are induced by multiple genetic and environmental risk factors $(4,5)$. Therapeutic approaches for IPF have changed from inflammation suppression to antifibrotic treatment and comorbidity management in recent years $(5,6)$. However, no treatment has been demonstrated to significantly decrease mortality (7). It was reported that median survival time of IPF was 2-5 years after diagnosis, with significant variation across countries $(3,8,9)$. Several features including level of dyspnea, extent of fibrosis, pulmonary function and comorbidities were indicated to correlate with survival in IPF (1). Among which, deterioration of pulmonary function, comprising ventilating and diffusing capacity, is clearly an important predictor for disease progression and prognosis (1). Currently there are only two drugs, nintedanib and pirfenidone, being proved to improve lung function $(7,10)$. With limited options, novel treatment strategy is the need of the hour.

Gastroesophageal reflux (GER) and GER disease (GERD) have been regarded as a common comorbidity of IPF, with a prevalence of 0 to $94 \%$ across different cohorts (2,11-13). The GER and consequent micro-aspiration of gastric juice, acidic and nonacidic mixtures, could play momentous roles in pathogenesis and progression of IPF (13-15). It was reported that alveolar and bronchial epithelial cells were exquisitely sensitive to acid-mediated and nonacidmediated triggers, which could increase cell membrane permeability, further induce airway inflammation and lung remodeling in animal models (16-18). Treatment for GER, mainly comprising acid suppressive agents and laparoscopic anti-reflux surgery (LARS), has been considered could improve clinical outcomes in patients with $\operatorname{IPF}(11,19,20)$. Currently, researches on anti-reflux therapy in IPF mainly focus on cough frequency, lung function and survival, and the majority is non-randomized controlled trials (RCTs) (21-25). Therefore, effect of anti-reflux therapy has been controversial, especially after the 2015 American Thoracic Society (ATS)/European Respiratory Society (ERS)/Japanese Respiratory Society (JRS)/Latin American Thoracic Society (ALAT) guideline conditionally recommended a regular acid suppressive therapy in IPF (19). There are only two relevant meta-analyses being found after a wide-range search, which are mainly focused on mortality, indicating anti-reflux therapy may be ineffective when avoiding immortal time bias $(24,25)$. However, pooled analysis on pulmonary function is still lacking.

Several observational studies suggested that antireflux therapy did not mitigate deterioration of forced vital capacity (FVC)\% predicted and diffusing capacity of the lung for carbon monoxide (DLCO)\% predicted in IPF (26-28). One RCT further observed worse FVC in the omeprazole group (23). While another two reports observed that anti-reflux therapy alleviated decline in ventilating capacity $(29,30)$. Therefore, to provide the latest and comprehensive evidence, we systematically reviewed the current available literature and conducted this study to evaluate effect of anti-reflux therapy on pulmonary function, including ventilating and diffusing capacity, in IPF patients. We also explored association between anti-reflux therapy and exercise capacity, measured with six-minute walking distance (6MWD).

We present the following article in accordance with the PRISMA reporting checklist (31) (available at https://dx.doi. org/10.21037/jtd-21-771).

\section{Methods}

\section{Literature search and selection criteria}

PubMed (1965 to September 2020), Embase (1974 to September 2020) and CENTRAL (1996 to September 2020) were searched for records related to anti-reflux therapy for IPF by two reviewers (M Yang and J Dong). The search strategy is shown in Table 1. The final search was conducted on September 15, 2020. English-language restriction was applied. The titles and abstracts were identified for all search results. The reference lists of eligible studies and relevant review articles were also hand-searched to find additional reports. Studies meeting the following criteria were selected: (I) population: adult patients diagnosed with IPF according to guideline criteria $(1,32)$; (II) intervention: anti-reflux therapy (pharmacologic or non-pharmacologic); (III) comparison: placebo or no anti-reflux therapy; (IV) outcome: pulmonary function (ventilating and diffusing capacity) and 6MWD; (V) study design: RCTs, observational and pre-post studies. If the title of an article or its abstract suggested any possibility that it might be relevant, both investigators reviewed its contents and assessed for a final decision about inclusion. 
Table 1 Search strategy

Search term
1. (Gastroesophageal reflux treatment) OR (anti-reflux surgery) OR (antacid therapy) OR (proton pump inhibitor)
OR (H2-receptor antagonist)
2. (Idiopathic pulmonary fibrosis) OR (pulmonary fibrosis) OR (Idiopathic pulmonary disease) OR (parenchymal lung disease)
3. (Pulmonary function) OR (lung function) OR FVC OR DLCO OR 6MWD

1 AND 2 AND 3

FVC, forced vital capacity; DLCO, diffusing capacity of the lung for carbon monoxide; 6MWD, six-minute walking distance.

Discrepancies in study inclusion were discussed amongst all authors until consensus was achieved.

\section{Data extraction}

Data extraction was performed by two reviewers (M Yang and $\mathrm{J}$ An) independently. The following information was extracted from each eligible study: publication year, first author, country, study design and duration, number of participants, baseline characteristics of participants, interventions, outcomes concerning lung function and 6MWD. We attempted to contact study authors in the case of missing data, as well as to clarify study outcomes to allow for meta-analysis where appropriate.

\section{Outcomes}

The primary outcomes were $\mathrm{FVC} \%$ predicted and DLCO $\%$ predicted reported after any treatment duration. Secondary outcomes included change in FVC and 6MWD reported after any treatment duration.

\section{Risk of bias and quality assessment}

The Cochrane risk of bias tool was adopted to assess the risk of bias for RCT. Details concerning random sequence generation, allocation concealment, blinding of participants and personnel, blinding of outcome assessment, incomplete outcome data, selective reporting and other biases were fully assessed in RCT. The judgments were expressed as "low risk", "high risk", or "unclear risk" of bias. For observational studies, the NewcastleOttawa Scale was used (33), and a total score $\leq 5$ indicated a high risk of bias (34). The Grades of Recommendation, Assessment, Development and Evaluation (GRADE) working group system was applied to assess overall quality of evidence for each outcome (35). We considered within-study risk of bias, directness of evidence, heterogeneity, precision of effect estimates and risk of publication bias in evaluating quality of evidence. We also investigated the influence of a single study on the overall pooled estimate by omitting one study in each turn for all studies.

\section{Statistical analysis}

Data were analyzed for RCTs and observational studies. Post-hoc analysis of RCTs was considered equivalent to observational study. According to data format (continuous), pooled measures were expressed as mean difference (MD) with $95 \%$ confidence interval (CI). Statistical heterogeneity was tested with the $\mathrm{I}^{2}$ statistic, a quantitative measure for inconsistency across studies. $\mathrm{I}^{2}$ statistic $>50 \%$ indicates significant heterogeneity (36). According to $\mathrm{I}^{2}$ statistic value, the inverse-variance method with fixed-effect model was used to calculate pooled MDs and $95 \%$ CIs. P value $<0.05$ was considered statistically significant, except where otherwise specified. All statistical analyses were performed using review manager (RevMan) (computer program), version 5.4, the Cochrane collaboration, 2020.

\section{Results}

\section{Study selection}

A total of 1,692 records were identified from the initial search. One hundred and sixty records were excluded for duplication. In total, 1,511 were removed for other reasons based on the titles and abstracts (reviews, unrelated abstracts, animal studies or other irrelevant studies). Six were removed for uncorrelated outcomes (survival rate or cough frequency) after full-text article assessment. Finally, 15 studies were included in qualitative analysis $(23,26-30,37-45)$ and nine were included in quantitative analysis $(23,26-29,37-39,45)$. All the 15 studies reported at least one primary or secondary outcome. The selection process was shown in Figure 1. The Cohen k statistic 


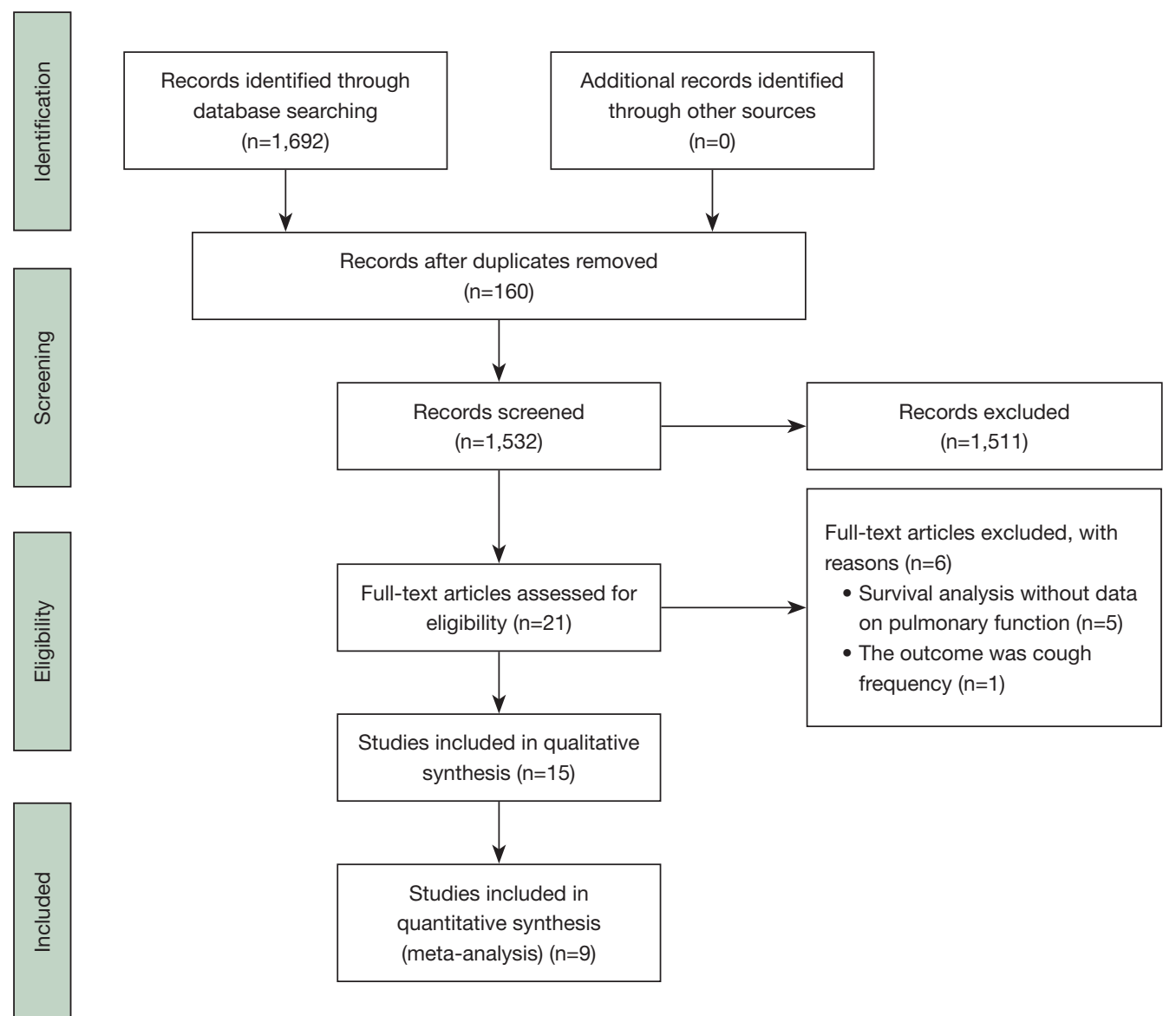

Figure 1 Flowchart of study selection.

for agreement on study inclusion was more than 0.9.

\section{Study characteristics and quality assessment}

Main characteristics and risk of bias assessment were presented in Tables 2,3 and Tables S1,S2. All studies were published between 2011-2019 and in English. The sample size ranged from 4 to 638 . Two studies were RCTs $(23,45)$ and others were observational studies (26-30,37-44). Six were multicenter studies enrolling patients from Americas, Europe, Asia and Oceania (29,37-40,45). Eight were singlecenter studies $(23,26-28,30,41,42,44)$ and the majority was conducted in the United States $(26,28,30,41,42,44)$. Participants were diagnosed with IPF according to the ATS/ ERS/JRS/ALAT criteria (1), with the mean age ranging from 65 to 72 years. Therapeutic intervention in four studies was LARS (42-45) while acid suppressive agents [proton pump inhibitor (PPI) and H2-receptor antagonist (H2RA)] were applied in the other 11 studies (23,26-30,37-41). Compared with control groups, GER was more frequent in treatment groups. Across these studies, prevalence of GER in treatment groups were $51.7-89 \%$, while in control groups was $5.8-60 \%$ (27-29,38-41). Based on the Newcastle-Ottawa Scale rating, 10 observational studies were rated as a total score of $>5$ $(26-30,37-39,42,44)$ and two studies as a score of $\leq 5(40,41)$, indicating a high risk of bias (Table S2). One study published in abstract form was not assessed because of full details not available (43).

Among the 15 studies, nine were included in quantitative analysis (23,26-29,37-39,45). They all have independent control groups, without a high risk of bias (score of $>5$ ). Particularly, the study by Ulrich Costabel comprised two parts. In one part (Costabel 1), all participants were taking nintedanib while patients in the other part (Costabel 2) were not taking (37). Data on the two parts were analyzed separately. 
Table 2 Risk of bias assessment of the randomized controlled trial

\begin{tabular}{|c|c|c|c|c|c|c|c|}
\hline Study & $\begin{array}{c}\text { Random } \\
\text { sequence } \\
\text { generation? }\end{array}$ & $\begin{array}{c}\text { Allocation } \\
\text { concealment? }\end{array}$ & $\begin{array}{c}\text { Blinding of participants, } \\
\text { personnel, and outcome } \\
\text { assessors? }\end{array}$ & $\begin{array}{c}\text { Incomplete } \\
\text { outcome data? }\end{array}$ & $\begin{array}{l}\text { Selective } \\
\text { reporting? }\end{array}$ & $\begin{array}{l}\text { Other } \\
\text { bias? }\end{array}$ & $\begin{array}{c}\text { Overall risk of } \\
\text { bias }\end{array}$ \\
\hline Raghu 2018 (45) & Yes & Yes & No & No & No & No & Low \\
\hline
\end{tabular}

Risk of bias was assessed using the Cochrane risk of bias tool.

\section{Primary outcomes}

Twelve studies reported FVC\% predicted and DLCO\% predicted during treatment (23,26-30,37-42), including 11 observational studies (26-30,37-42) and one RCT (23).

Among which, 10 (including the RCT) revealed no significant difference concerning $\mathrm{FVC} \%$ predicted and DLCO \% predicted between treatment groups and control groups $(23,26-29,37-39,41,42)$. In the RCT, compared with placebo group, FVC was significantly lower, while KCO (the transfer factor for carbon monoxide, TLCO, corrected for accessible alveolar volume) was apparently increased in omeprazole group (23). For the other two studies, one case series on four IPF patients taking PPIs showed stability of FVC\% predicted and DLCO $\%$ predicted during 2-6 years of follow-up (30). The study conducted by Helen E. Jo also indicated significant improvement of $\mathrm{FVC} \%$ predicted and DLCO\% predicted in treatment group (40). However, in this study, a significant difference on mean age of participants between groups was observed (71.6 vs. 69.7 respectively, $\mathrm{P}=0.008$ ), which weakened reliability of the results.

In quantitative analysis, pooled data on eight studies (23,26-29,37-39) showed anti-reflux therapy did not ameliorate $\mathrm{FVC} \%$ predicted (MD $=0.88,95 \% \mathrm{CI}:-0.22$ to $1.98, \mathrm{P}=0.12, \mathrm{I}^{2}=0 \%, 8$ studies, $\left.\mathrm{n}=3,076\right)$ and DLCO $\%$ predicted ( $\mathrm{MD}=0.75,95 \% \mathrm{CI}:-0.13$ to $1.62, \mathrm{P}=0.10, \mathrm{I}^{2}$ $=0 \%, 8$ studies, $\mathrm{n}=3,073)$. Further exclusion of any single study did not materially alter the overall combined MDs. As presented in Figures 2,3.

\section{Secondary outcomes}

Eight studies $(23,29,37-39,43-45)$ reported change in FVC during treatment. Four studies suggested no significant improvement in FVC in treatment groups (23,37-39). Similar results were also found in patients simultaneously taking pirfenidone or nintedanib and subgroups stratified by baseline 70\% predicted FVC (37-39). Inversely, four reports demonstrated non-significant decline in FVC after treatment, with at least 7-month follow-up (29,43-45). Among which three applied a self-controlled design. Five studies were further included in meta-analyses $(23,29,38,39,45)$. As shown in Table 4, pooled data indicated anti-reflux therapy did not significantly alleviate FVC decline $[\mathrm{MD}=0.02,95 \% \mathrm{CI}$ : -0.01 to $0.04, \mathrm{P}=0.29, \mathrm{I}^{2}=17 \%, 5$ studies $(23,29,38,39,45)$, $\mathrm{n}=1,586]$. Further exclusion of any single study did not materially alter the overall combined MD.

Six studies reported $6 \mathrm{MWD}$ during treatment, including two RCTs $(23,29,38,39,42,45)$, which unanimously suggested no apparent difference on 6MWD between groups. As presented in Table 4, quantitative analysis on four studies demonstrated anti-reflux therapy did not promote improvement of $6 \mathrm{MWD}$ in IPF $[\mathrm{MD}=-7.70,95 \% \mathrm{CI}$ : -17.61 to $2.20, \mathrm{P}=0.13, \mathrm{I}^{2}=0 \%, 4$ studies $(23,29,38,39)$, $\mathrm{n}=1,527]$. Further exclusion of any single study did not materially alter the overall combined MDs.

\section{Subgroup analysis}

LARS was reported in four studies (42-45). three reports with self-controlled design indicated non-significant decline in $\mathrm{FVC}$ or $\mathrm{FVC} \%$ predicted for at least 7 months after LARS (42-44) whereas another RCT showed no improvement in FVC compared with no surgery group (45). In 11 acid suppressive agents associated reports, PPI using was apparently more than H2RA (23,26-30,37-41). Participants using PPI accounted for $89.58 \%$ to $100 \%$ across studies. Ten studies revealed no statistical significance on FVC\% predicted and DLCO \% predicted (23,26-29,37-41), including two studies with $100 \%$ patients taking PPI $(23,26)$. As shown in Figures 2,3, quantitative analysis showed favorable effect of PPI on DLCO $\%$ predicted (MD $=4.90$, 95\% CI: 0.86 to $8.94, \mathrm{P}=0.02, \mathrm{I}^{2}=0 \%, 2$ studies, $\mathrm{n}=251$ ), while not significant in $\mathrm{FVC} \%$ predicted $(\mathrm{MD}=1.50$, 95\% CI: -3.01 to $6.00, \mathrm{P}=0.52, \mathrm{I}^{2}=59 \%, 2$ studies, $\mathrm{n}=254$ ). Quantitative analysis concerning LARS or H2RA was not conducted because the extracted data was limited. 
Table 3 Characteristics of included studies

\begin{tabular}{|c|c|c|c|c|c|c|c|c|}
\hline Author, year & Setting & Setting & Study design & $\begin{array}{l}\text { No. patients } \\
\text { [experimental/ } \\
\text { control] }\end{array}$ & $\begin{array}{c}\text { Age, years } \\
\text { (experimental/ } \\
\text { control) }\end{array}$ & $\begin{array}{c}\text { Gender } \\
\text { (F/M) }\end{array}$ & Intervention & $\begin{array}{c}\text { Newcastle- } \\
\text { Ottawa Scale } \\
\text { rating }\end{array}$ \\
\hline Jo, 2019, (40) & $\begin{array}{l}\text { Multicenter } \\
\text { (Australia) }\end{array}$ & $\begin{array}{l}\text { Multicenter } \\
\text { (Australia) }\end{array}$ & $\begin{array}{l}\text { Retrospective } \\
\text { cohort }\end{array}$ & 587 [384/203] & $72 \pm 8 / 70 \pm 9$ & $181 / 406$ & $\begin{array}{l}\text { PPI and/ } \\
\text { or H2RA }\end{array}$ & 5 \\
\hline $\begin{array}{l}\text { Kreuter, 2016, } \\
\text { (38) }\end{array}$ & $\begin{array}{l}\text { Multicenter (19 } \\
\text { countries") }^{\text {(1) }}\end{array}$ & $\begin{array}{l}\text { Multicenter } \\
\left(19 \text { countries }{ }^{n}\right)\end{array}$ & $\begin{array}{l}\text { Retrospective } \\
\text { cohort }\end{array}$ & 624 [291/333] & $67 \pm 7 / 67 \pm 8$ & $159 / 465$ & $\begin{array}{l}\text { PPI and/ } \\
\text { or H2RA }\end{array}$ & 8 \\
\hline Lee, 2013, (29) & $\begin{array}{l}\text { Multicenter } \\
\text { (United States) }\end{array}$ & $\begin{array}{l}\text { Multicenter } \\
\text { (United States) }\end{array}$ & $\begin{array}{l}\text { Retrospective } \\
\text { cohort }\end{array}$ & 242 [124/118] & $68 \pm 8 / 67 \pm 9$ & $52 / 190$ & $\begin{array}{l}\text { PPI and/ } \\
\text { or H2RA }\end{array}$ & 7 \\
\hline $\begin{array}{l}\text { Linden, 2006, } \\
\text { (42) }\end{array}$ & $\begin{array}{l}\text { Single center } \\
\text { (United States) }\end{array}$ & $\begin{array}{l}\text { Single center } \\
\text { (United States) }\end{array}$ & $\begin{array}{l}\text { Retrospective } \\
\text { cohort }\end{array}$ & $45[14 / 31]$ & NR & NR & $\begin{array}{c}\text { Nissen } \\
\text { fundoplication }\end{array}$ & 6 \\
\hline Liu, 2017, (27) & $\begin{array}{l}\text { Single center } \\
\text { (China) }\end{array}$ & $\begin{array}{l}\text { Single center } \\
\text { (China) }\end{array}$ & $\begin{array}{l}\text { Retrospective } \\
\text { cohort }\end{array}$ & 69 [34/35] & $67 \pm 7 / 70 \pm 5$ & $23 / 46$ & $\begin{array}{l}\text { PPI or } \\
\text { H2RA }\end{array}$ & 7 \\
\hline $\begin{array}{l}\text { Noth, 2012, } \\
\text { (41) }\end{array}$ & $\begin{array}{l}\text { Single center } \\
\text { (United States) }\end{array}$ & $\begin{array}{l}\text { Single center } \\
\text { (United States) }\end{array}$ & $\begin{array}{l}\text { Retrospective } \\
\text { cohort }\end{array}$ & 74 [35/39] & $68 / 65$ & NR & $\begin{array}{l}\text { PPI and/ } \\
\text { or H2RA }\end{array}$ & 4 \\
\hline $\begin{array}{l}\text { Raghu, 2016, } \\
\text { (44) }\end{array}$ & $\begin{array}{l}\text { Single center } \\
\text { (United States) }\end{array}$ & $\begin{array}{l}\text { Single center } \\
\text { (United States) }\end{array}$ & $\begin{array}{l}\text { Retrospective } \\
\text { self-controlled }\end{array}$ & 27 [NA] & $65[51-77]^{8}$ & $12 / 15$ & LARS & 6 \\
\hline $\begin{array}{l}\text { Raghu, 2018, } \\
\text { (45) (RCT) }\end{array}$ & $\begin{array}{l}\text { Multicenter } \\
\text { (United States) }\end{array}$ & $\begin{array}{l}\text { Multicenter } \\
\text { (United States) }\end{array}$ & $\mathrm{RCT}$ & 58 [29/29] & $71 \pm 6 / 69 \pm 7$ & $11 / 47$ & LARS & NA \\
\hline $\begin{array}{l}\text { Costabel } 1^{*} \text {, } \\
2018,(37)\end{array}$ & $\begin{array}{l}\text { Multicenter (24 } \\
\left.\text { countries }^{\S}\right)\end{array}$ & $\begin{array}{l}\text { Multicenter } \\
\left(24 \text { countries }^{\S}\right)\end{array}$ & $\begin{array}{l}\text { Retrospective } \\
\text { cohort }\end{array}$ & 638 [244/394] & $67 \pm 8 / 66 \pm 8$ & $131 / 507$ & $\begin{array}{l}\text { PPI or } \\
\text { H2RA }\end{array}$ & 7 \\
\hline $\begin{array}{l}\text { Costabel 2", } \\
2018,(37)\end{array}$ & $\begin{array}{l}\text { Multicenter ( } 24 \\
\left.\text { countries }^{\S}\right)\end{array}$ & $\begin{array}{l}\text { Multicenter } \\
\left(24 \text { countries }^{\S}\right)\end{array}$ & $\begin{array}{l}\text { Retrospective } \\
\text { cohort }\end{array}$ & $423[162 / 261]$ & $68 \pm 7 / 66 \pm 8$ & $89 / 334$ & $\begin{array}{l}\text { PPI or } \\
\text { H2RA }\end{array}$ & 7 \\
\hline
\end{tabular}

Data are presented as $\mathrm{n}$, median (interquartile range) or mean \pm SD unless otherwise stated. ", Australia, Belgium, Brazil, Canada, Croatia, France, Germany, Ireland, Israel, Italy, Mexico, New Zealand, Peru, Poland, Singapore, Spain, Switzerland, United Kingdom, United States;

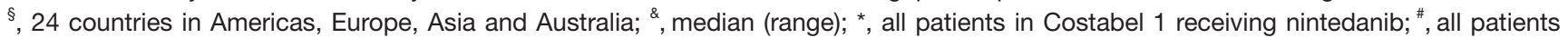
in Costabel 2 not taking nintedanib. RCT, randomized controlled trial; PPI, proton pump inhibitor; NA, not applicable; H2RA, H2-receptor antagonist; NR, not reported; LARS, laparoscopic anti-reflux surgery. 


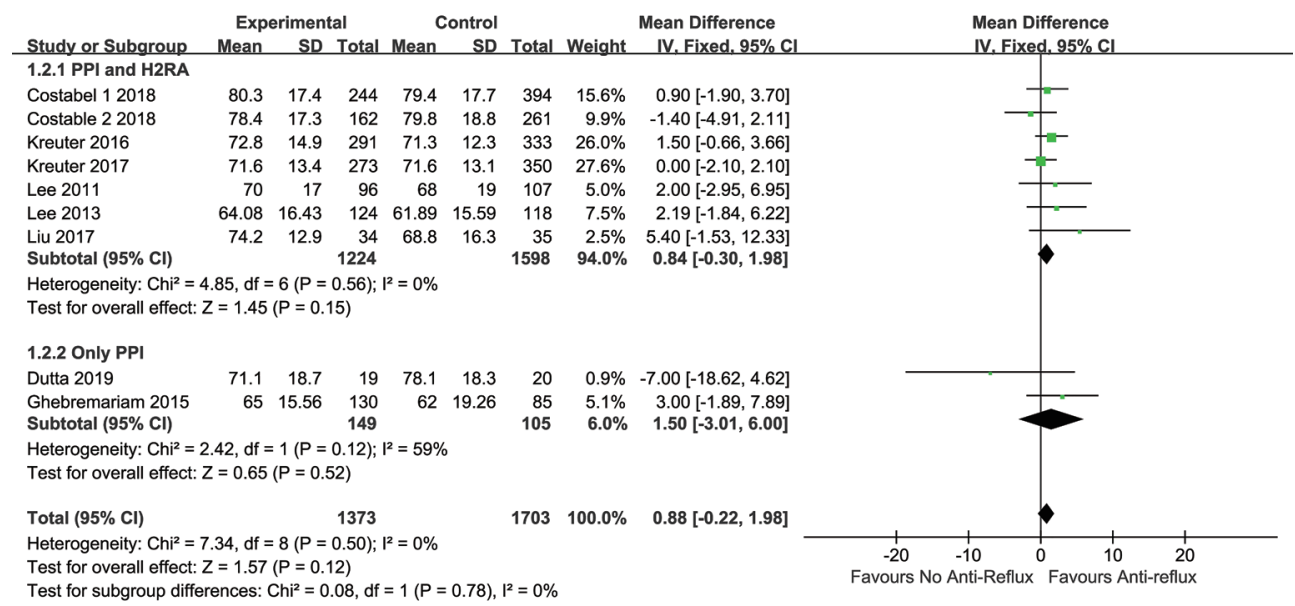

Figure 2 Effect of anti-reflux therapy on FVC\% predicted in IPF. CI, confidence interval; FVC, forced vital capacity; IPF, idiopathic pulmonary fibrosis; SD, standard deviation.

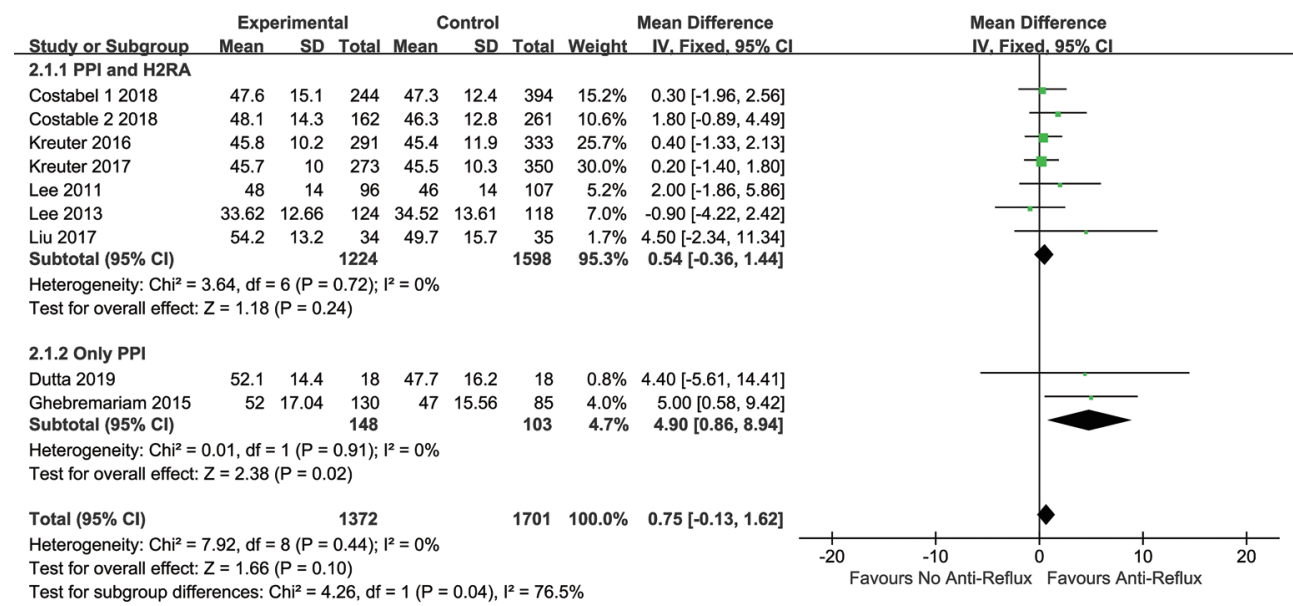

Figure 3 Effect of anti-reflux therapy on DLCO\% predicted in IPF. CI, confidence interval; DLCO, diffusing capacity of the lung for carbon monoxide; IPF, idiopathic pulmonary fibrosis; SD, standard deviation.

Six studies investigated IPF subgroup with GER, but with different study designs (30,41-45). Detailed characteristics were summarized in Table 5. Four selfcontrolled studies unanimously showed potentially improved FVC\% predicted (30,42-44). However, in the other two studies with better designs, similar result was not indicated $(41,45)$. Quantitative analysis was not performed because of identified heterogeneity across studies. Additionally, three studies enrolling patients taking nintedanib or pirfenidone at the same time. They demonstrated the addition of anti-reflux therapy could not further improve pulmonary function (37-39).

\section{Grading the quality of evidence}

As shown in Table 6 and the supplementary material (Appendix 1), the quality of evidence for outcomes on FVC\% predicted, DLCO $\%$ predicted and change in FVC was judged as low due to serious risk of bias, which was upgraded because all plausible confounding would reduce demonstrated effect. The quality of evidence for outcome on $6 \mathrm{MWD}$ was judged as very low due to serious risk of bias and serious imprecision, which was upgraded because all plausible confounding would reduce demonstrated effect. 
Table 4 Effect of anti-reflux therapy on change in FVC and 6MWD

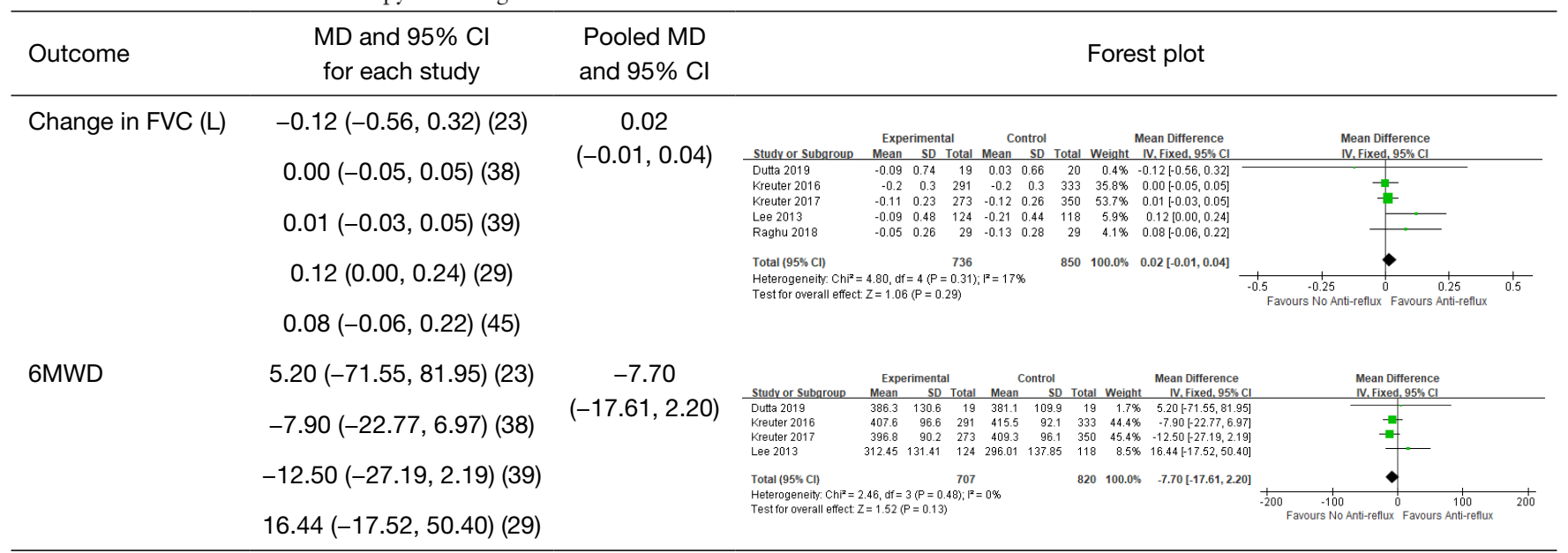

FVC, forced vital capacity; 6MWD, six-minute walking distance; MD, mean difference; Cl, confidence interval; SD, standard deviation.

Table 5 Studies on IPF subgroup with GER

\begin{tabular}{|c|c|c|c|c|c|c|}
\hline Study & $\begin{array}{l}\text { Experiment } \\
\text { group }\end{array}$ & $\begin{array}{l}\text { Control } \\
\text { group }\end{array}$ & Assessment of GER & $\begin{array}{l}\text { Therapeutic } \\
\text { intervention }\end{array}$ & Follow-up & Results \\
\hline Linden 2006, (42) & $\begin{array}{l}\text { GERD } \\
\text { (post-LARS) }\end{array}$ & $\begin{array}{l}\text { GERD } \\
\text { (pre-LARS) }\end{array}$ & $\begin{array}{l}\text { Symptoms, endoscopy and } \\
\text { ambulatory } \mathrm{pH} \text { monitoring }\end{array}$ & LARS & 15 months & $\begin{array}{l}\text { No significant decline in } \\
\text { FVC\% predicted and DLCO\% } \\
\text { predicted }\end{array}$ \\
\hline Noth 2012, (41) & GER & No GER & $\begin{array}{l}\text { Symptoms and ambulatory } \\
\mathrm{pH} \text { monitoring }\end{array}$ & PPI or H2RA & NA & $\begin{array}{l}\text { FVC\% predicted and DLCO\% } \\
\text { predicted were higher in GER } \\
\text { group but not significant }\end{array}$ \\
\hline $\begin{array}{l}\text { Raghu 2006, (30) } \\
\text { (case report) }\end{array}$ & $\begin{array}{l}\text { GER } \\
\text { (end-point) }\end{array}$ & $\begin{array}{l}\text { GER } \\
\text { (baseline) }\end{array}$ & $\begin{array}{l}\text { Symptoms and } 24 \text {-hour } \\
\text { esophageal pH study }\end{array}$ & PPI & $\begin{array}{l}24-72 \\
\text { months }\end{array}$ & $\begin{array}{l}\text { FVC\% predicted and DLCO\% } \\
\text { predicted were stable } \\
\text { compared to baseline }\end{array}$ \\
\hline $\begin{array}{l}\text { Raghu } 2013 \text { (43) } \\
\text { (abstract) }\end{array}$ & $\begin{array}{l}\text { GER } \\
\text { (post-LARS) }\end{array}$ & $\begin{array}{l}\text { GER } \\
\text { (pre-LARS) }\end{array}$ & $\begin{array}{l}\text { 24-hour esophageal pH } \\
\text { study }\end{array}$ & LARS & 7 months & $\begin{array}{l}\text { Mean FVC increased by } \\
0.08 \text { L (3.5\% predicted) }\end{array}$ \\
\hline $\begin{array}{l}\text { Raghu 2018, (45) } \\
\text { (RCT) }\end{array}$ & $\begin{array}{l}\text { GER } \\
\text { (surgery) }\end{array}$ & $\begin{array}{l}\text { GER } \\
\text { (no surgery) }\end{array}$ & $\begin{array}{l}\text { 24-hour esophageal pH } \\
\text { study }\end{array}$ & LARS & 52 weeks & $\begin{array}{l}\text { No significant difference on } \\
\text { FVC decline over } 48 \text { weeks } \\
\text { between groups }\end{array}$ \\
\hline
\end{tabular}

IPF, idiopathic pulmonary fibrosis; GER, gastroesophageal reflux; GERD, GER disease; LARS, laparoscopic anti-reflux surgery; FVC, forced vital capacity; DLCO, diffusing capacity of the lung for carbon monoxide; PPI, proton pump inhibitor; H2RA, H2-receptor antagonist; NA, not available; RCT, randomized controlled trial.

\section{Discussion}

This study systematically summarized and evaluated effect of anti-reflux therapy, comprising acid suppressive agents and LARS, on pulmonary function in patients with IPF. The main findings suggested anti-reflux therapy did not ameliorate pulmonary function and 6MWD. However, as the majority of included studies was observational and retrospective, our confidence in the results was low.

The progressive interstitial fibrosis in IPF induces continuous impairment of lung function. Amelioration of lung function has been closely associated with better quality 
Table 6 Overall quality of evidence for each outcome

\begin{tabular}{ll}
\hline Outcome & Certainty of the evidence GRADE \\
\hline FVC\% predicted & $\oplus \oplus$ Low \\
DLCO\% predicted & $\oplus \oplus$ Low \\
Change in FVC & $\oplus \oplus$ Low \\
6MWD & $\oplus$ Very low \\
\hline
\end{tabular}

Quality of evidence for each outcome was assessed using the GRADE criteria. GRADE, the Grades of Recommendation, Assessment, Development and Evaluation; FVC, forced vital capacity; DLCO, diffusing capacity of the lung for carbon monoxide; 6MWD, six-minute walking distance.

of live and prognosis. The hypothesis of anti-reflux therapy for IPF is mainly based on its effect of reducing aspiration or micro-aspiration $(2,14,16)$. Besides, emerging data indicate extending effects of PPIs concerning suppression of airways inflammation and regulation of immune, further indicating the possibility to be applied in IPF (46). However, these hypotheses seem not to be supported by clinical investigations, which have revealed inconsistent findings during the past few decades (2). The meta-analysis by Lee Fidler summarized data from three retrospective studies and showed acid suppressive agents did not slow annual decline in FVC (24). After this meta-analysis, several relevant reports were published $(23,37,40,45)$, including RCTs $(23,45)$. Based on current clinical data, we conducted this study to firstly provide a comprehensive overview with regard to effect of anti-reflux therapy on lung function in IPF. After a wide-range literature search, we found that therapeutic interventions across studies mainly comprised PPIs, H2RA and LARS. To sum up, qualitative and quantitative analyses preliminarily suggested anti-reflux therapy could not mitigate deterioration of pulmonary function and 6MWD in patients with IPF, also may not impact the treatment effect of nintedanib or pirfenidone (37-39). There were only two articles reporting significantly improved $\mathrm{FVC} \%$ predicted and DLCO $\%$ predicted after anti-reflux therapy $(30,40)$. However, one was a case report only enrolling four patients (30) and in the other one, there existed poor comparability on mean age of participants between groups, as mentioned above (40). It is worth noting that, results in the present study could not challenge the recommendation of the ATS/ERS/JRS/ALAT guideline because most included studies were non-RCTs (19).

Although GER is highly prevalent in patients with IPF, it remains undetermined whether anti-reflux therapy is exclusively effective for IPF with GER. Currently, the majority of studies on this subgroup are focused on LARS and with self-controlled design (42-44), which tends to show that LARS may mitigated FVC decline. However, considering limitation in study design, small sample size, and discrepancy induced by different interventions (acid suppressive agents $v s$. surgery), it should be careful to interpret these findings. By contrast, subgroup analysis of our study suggested studies with better design showed nonsignificant effect of anti-reflux therapy. Therefore, future advanced research is warranted.

Additionally, two intriguing findings regarding therapeutic interventions were detected. Firstly, effect of acid suppressive agents and LARS could be different. As described above, investigations on LARS showed mitigated FVC decline for at least seven months (42-44), which was not duplicated in studies on acid suppressive agents (23,37-39). LARS has been reported to provide effective control of GER in more than $90 \%$ of cases, suggesting more effective than acid suppressive agents (47). Besides, durable long-term effect and improved quality of life are also observed in patients undergoing LARS $(48,49)$. However, in the RCT by Ganesh Raghu (45), difference regarding adjusted rate of change in FVC over 48 weeks was non-significant between surgery and no surgery groups. This might indicate previously observed benefit of LARS was induced by low-quality study design. Meanwhile, nearly all patients receive treatment of acid suppressive agents before undergoing LARS $(43,45)$. This could induce falsepositive findings concerning LARS.

Secondly, difference between PPIs and H2RA should also be noted, and PPIs could be more valuable. Molecular and cell biological studies found that PPIs favorably regulated the oxidant-antioxidant system and suppressed key inflammatory molecules in tracheal epithelial cells, which were not reproduced in H2RA (50-52). Clinical study by Joyce S. Lee demonstrated alleviated FVC decline among patients taking PPIs or H2RA, and similar result was also observed when excluding H2RA (29). Stable fluctuation of pulmonary function during at least two years was also indicated in patients taking PPIs only (30). Our subgroup analysis presented significant benefit of PPI for improving DLCO \% predicted. Similar result was not underlined in studies enrolling patients taking H2RA.

Several potential limitations should be noted when interpreting the present results.

First, the majority of included studies are observational database studies, which are highly subject to selection bias, 
database related error (53) and confounding by indication. Second, although no apparent heterogeneity was observed for all outcomes, population characteristics and lung function varied across studies. We failed to conduct detailed subgroup analyses with respect to potential confounding factors, such as GER, therapeutic measure (acid suppressive agents or LARS) and study design (RCT or non-RCT), but an influence analysis was performed to add robustness. Third, not all studies provided detailed information of antireflux medication including type, dose and duration, which undermined reliability of the present results.

\section{Conclusions}

In conclusion, this systematic review and meta-analysis preliminarily indicates that anti-reflux therapy may not ameliorate pulmonary function deterioration in IPF. Our confidence in the results is limited because of lacking RCTs. Although current guideline recommends application of acid suppressive agent therapy in IPF, high-quality RCT on specific subgroup suitable for anti-reflux therapy is warranted.

\section{Acknowledgments}

Funding: None.

\section{Footnote}

Reporting Checklist: The authors have completed the PRISMA reporting checklist. Available at https://dx.doi. org/10.21037/jtd-21-771

Peer Review File: Available at https://dx.doi.org/10.21037/ jtd-21-771

Conflicts of Interest: All authors have completed the ICMJE uniform disclosure form (available at https://dx.doi. org/10.21037/jtd-21-771). The authors have no conflicts of interest to declare.

Ethical Statement: The authors are accountable for all aspects of the work in ensuring that questions related to the accuracy or integrity of any part of the work are appropriately investigated and resolved.

Open Access Statement: This is an Open Access article distributed in accordance with the Creative Commons Attribution-NonCommercial-NoDerivs 4.0 International License (CC BY-NC-ND 4.0), which permits the noncommercial replication and distribution of the article with the strict proviso that no changes or edits are made and the original work is properly cited (including links to both the formal publication through the relevant DOI and the license). See: https://creativecommons.org/licenses/by-nc-nd/4.0/.

\section{References}

1. Raghu G, Collard HR, Egan JJ, et al. An official ATS/ ERS/JRS/ALAT statement: idiopathic pulmonary fibrosis: evidence-based guidelines for diagnosis and management. Am J Respir Crit Care Med 2011;183:788-824.

2. Johannson KA, Strâmbu I, Ravaglia C, et al. Antacid therapy in idiopathic pulmonary fibrosis: more questions than answers? Lancet Respir Med 2017;5:591-8.

3. Hutchinson J, Fogarty A, Hubbard R, et al. Global incidence and mortality of idiopathic pulmonary fibrosis: a systematic review. Eur Respir J 2015;46:795-806.

4. Richeldi L, Collard HR, Jones MG. Idiopathic pulmonary fibrosis. Lancet 2017;389:1941-52.

5. Selman M, King TE, Pardo A, et al. Idiopathic pulmonary fibrosis: prevailing and evolving hypotheses about its pathogenesis and implications for therapy. Ann Intern Med 2001;134:136-51.

6. Somogyi V, Chaudhuri N, Torrisi SE, et al. The therapy of idiopathic pulmonary fibrosis: what is next? Eur Respir Rev 2019;28:190021.

7. Canestaro WJ, Forrester SH, Raghu G, et al. Drug Treatment of Idiopathic Pulmonary Fibrosis: Systematic Review and Network Meta-Analysis. Chest 2016;149:756-66.

8. Nalysnyk L, Cid-Ruzafa J, Rotella P, et al. Incidence and prevalence of idiopathic pulmonary fibrosis: review of the literature. Eur Respir Rev 2012;21:355-61.

9. Gay SE, Kazerooni EA, Toews GB, et al. Idiopathic pulmonary fibrosis: predicting response to therapy and survival. Am J Respir Crit Care Med 1998;157:1063-72.

10. Richeldi L, Varone F, Bergna M, et al. Pharmacological management of progressive-fibrosing interstitial lung diseases: a review of the current evidence. Eur Respir Rev 2018;27:180074.

11. Raghu G, Amatto VC, Behr J, et al. Comorbidities in idiopathic pulmonary fibrosis patients: a systematic 
literature review. Eur Respir J 2015;46:1113-30.

12. Tobin RW, Pope CE 2nd, Pellegrini CA, et al. Increased prevalence of gastroesophageal reflux in patients with idiopathic pulmonary fibrosis. Am J Respir Crit Care Med 1998;158:1804-8.

13. Wang Z, Bonella F, Li W, et al. Gastroesophageal Reflux Disease in Idiopathic Pulmonary Fibrosis: Uncertainties and Controversies. Respiration 2018;96:571-87.

14. Raghu G, Meyer KC. Silent gastro-oesophageal reflux and microaspiration in IPF: mounting evidence for anti-reflux therapy? Eur Respir J 2012;39:242-5.

15. Han MK. High prevalence of abnormal acid gastrooesophageal reflux in idiopathic pulmonary fibrosis. Eur Respir J 2006;28:884-5; author reply 885.

16. Ghebre YT, Raghu G. Idiopathic Pulmonary Fibrosis: Novel Concepts of Proton Pump Inhibitors as Antifibrotic Drugs. Am J Respir Crit Care Med 2016;193:1345-52.

17. Perng DW, Chang KT, Su KC, et al. Exposure of airway epithelium to bile acids associated with gastroesophageal reflux symptoms: a relation to transforming growth factorbeta 1 production and fibroblast proliferation. Chest 2007;132:1548-56.

18. Appel JZ 3rd, Lee SM, Hartwig MG, et al. Characterization of the innate immune response to chronic aspiration in a novel rodent model. Respir Res 2007;8:87.

19. Raghu G, Rochwerg B, Zhang Y, et al. An Official ATS/ ERS/JRS/ALAT Clinical Practice Guideline: Treatment of Idiopathic Pulmonary Fibrosis. An Update of the 2011 Clinical Practice Guideline. Am J Respir Crit Care Med 2015;192:e3-19.

20. Ghebre Y, Raghu G. Proton pump inhibitors in IPF: beyond mere suppression of gastric acidity. QJM 2016;109:577-9.

21. Kreuter M, Lederer DJ, Cottin V, et al. Concomitant medications and clinical outcomes in idiopathic pulmonary fibrosis. Eur Respir J 2019;54:1901188.

22. Ghebre YT. Proton Pump Inhibitors in IPF: A Call for Clinical Trials. Front Pharmacol 2018;9:499.

23. Dutta P, Funston W, Mossop H, et al. Randomised, double-blind, placebo-controlled pilot trial of omeprazole in idiopathic pulmonary fibrosis. Thorax 2019;74:346-53.

24. Fidler L, Sitzer N, Shapera S, et al. Treatment of Gastroesophageal Reflux in Patients With Idiopathic Pulmonary Fibrosis: A Systematic Review and MetaAnalysis. Chest 2018;153:1405-15.

25. Tran T, Suissa S. The effect of anti-acid therapy on survival in idiopathic pulmonary fibrosis: a methodological review of observational studies. Eur Respir J 2018;51:1800376.
26. Ghebremariam Y'T, Cooke JP, Gerhart W, et al. Pleiotropic effect of the proton pump inhibitor esomeprazole leading to suppression of lung inflammation and fibrosis. J Transl Med 2015;13:249.

27. Liu B, Su F, Xu N, et al. Chronic use of anti-reflux therapy improves survival of patients with pulmonary fibrosis. Int $\mathrm{J}$ Clin Exp Med 2017;10:5805-10.

28. Lee JS, Ryu JH, Elicker BM, et al. Gastroesophageal reflux therapy is associated with longer survival in patients with idiopathic pulmonary fibrosis. Am J Respir Crit Care Med 2011;184:1390-4.

29. Lee JS, Collard HR, Anstrom KJ, et al. Anti-acid treatment and disease progression in idiopathic pulmonary fibrosis: an analysis of data from three randomised controlled trials. Lancet Respir Med 2013;1:369-76.

30. Raghu G, Yang ST, Spada C, et al. Sole treatment of acid gastroesophageal reflux in idiopathic pulmonary fibrosis: a case series. Chest 2006;129:794-800.

31. Moher D, Shamseer L, Clarke M, et al. Preferred reporting items for systematic review and meta-analysis protocols (PRISMA-P) 2015 statement. Syst Rev 2015;4:1.

32. American Thoracic Society. Idiopathic pulmonary fibrosis: diagnosis and treatment. International consensus statement. American Thoracic Society (ATS), and the European Respiratory Society (ERS). Am J Respir Crit Care Med 2000;161:646-64.

33. Wells GA, Shea B, O'Connell D, et al. The NewcastleOttawa Scale (NOS) for assessing the quality of nonrandomized studies in meta-analyses. Available online: http://www.ohri.ca/programs/clinical_epidemiology/ oxford.asp

34. Gu WJ, Wang F, Tang L, et al. Single-dose etomidate does not increase mortality in patients with sepsis: a systematic review and meta-analysis of randomized controlled trials and observational studies. Chest 2015;147:335-46.

35. Higgins JPT, Green S. Cochrane handbook for systematic reviews of interventions version 5.1.0. The Cochrane Collaboration, 2011.

36. Higgins JP, Thompson SG, Deeks JJ, et al. Measuring inconsistency in meta-analyses. BMJ 2003;327:557-60.

37. Costabel U, Behr J, Crestani B, et al. Anti-acid therapy in idiopathic pulmonary fibrosis: insights from the INPULSIS® trials. Respir Res 2018;19:167.

38. Kreuter M, Wuyts W, Renzoni E, et al. Antacid therapy and disease outcomes in idiopathic pulmonary fibrosis: a pooled analysis. Lancet Respir Med 2016;4:381-9.

39. Kreuter M, Spagnolo P, Wuyts W, et al. Antacid Therapy and Disease Progression in Patients with Idiopathic 
Pulmonary Fibrosis Who Received Pirfenidone.

Respiration 2017;93:415-23.

40. Jo HE, Corte TJ, Glaspole I, et al. Gastroesophageal reflux and antacid therapy in IPF: analysis from the Australia IPF Registry. BMC Pulm Med 2019;19:84.

41. Noth I, Zangan SM, Soares RV, et al. Prevalence of hiatal hernia by blinded multidetector CT in patients with idiopathic pulmonary fibrosis. Eur Respir J 2012;39:344-51.

42. Linden PA, Gilbert RJ, Yeap BY, et al. Laparoscopic fundoplication in patients with end-stage lung disease awaiting transplantation. J Thorac Cardiovasc Surg 2006;131:438-46.

43. Raghu G, Mart D, Anstrom KJ, et al. Treatment of Idiopathic Pulmonary Fibrosis (IPF) with Laparoscopic Anti-Reflux Surgery (LARS) Is Associated With Improvement In Forced Vital Capacity (FVC). American Journal of Respiratory and Critical Care Medicine 2013;187:A5711.

44. Raghu G, Morrow E, Collins BF, et al. Laparoscopic antireflux surgery for idiopathic pulmonary fibrosis at a single centre. Eur Respir J 2016;48:826-32.

45. Raghu G, Pellegrini CA, Yow E, et al. Laparoscopic antireflux surgery for the treatment of idiopathic pulmonary fibrosis (WRAP-IPF): a multicentre, randomised, controlled phase 2 trial. Lancet Respir Med 2018;6:707-14.

46. Kedika RR, Souza RF, Spechler SJ. Potential antiinflammatory effects of proton pump inhibitors: a review and discussion of the clinical implications. Dig Dis Sci 2009;54:2312-7.

47. Bonatti H, Bammer T, Achem SR, et al. Use of acid

Cite this article as: Yang M, Dong J, An J, Liu L, Chen L. Effect of anti-reflux therapy on pulmonary function in idiopathic pulmonary fibrosis: a systematic review and metaanalysis. J Thorac Dis 2021;13(10):5776-5787. doi: 10.21037/ jtd-21-771 suppressive medications after laparoscopic antireflux surgery: prevalence and clinical indications. Dig Dis Sci 2007;52:267-72.

48. Catarci M, Gentileschi P, Papi C, et al. Evidencebased appraisal of antireflux fundoplication. Ann Surg 2004;239:325-37.

49. Kamolz T, Granderath FA, Bammer T, et al. "Floppy" Nissen vs. Toupet laparoscopic fundoplication: quality of life assessment in a 5-year follow-up (part 2). Endoscopy 2002;34:917-22.

50. Takagi T, Naito Y, Okada H, et al. Lansoprazole, a proton pump inhibitor, mediates anti-inflammatory effect in gastric mucosal cells through the induction of heme oxygenase-1 via activation of NF-E2-related factor 2 and oxidation of kelch-like ECH-associating protein 1. J Pharmacol Exp Ther 2009;331:255-64.

51. Yoshida N, Yoshikawa T, Tanaka Y, et al. A new mechanism for anti-inflammatory actions of proton pump inhibitors--inhibitory effects on neutrophil-endothelial cell interactions. Aliment Pharmacol Ther 2000;14 Suppl 1:74-81.

52. Sasaki T, Yamaya M, Yasuda H, et al. The proton pump inhibitor lansoprazole inhibits rhinovirus infection in cultured human tracheal epithelial cells. Eur J Pharmacol 2005;509:201-10.

53. Panchabhai TS, Arrossi AV, Highland KB, et al. A singleinstitution study of concordance of pathological diagnoses for interstitial lung diseases between pre-transplantation surgical lung biopsies and lung explants. BMC Pulm Med 2019;19:20. 


\section{Quality assessment for included studies}

This study included two randomized controlled trials (RCTs) and 13 observational studies. We used the Cochrane risk of bias tool to assess the quality of RCTs, and for observational studies, the Newcastle-Ottawa Scale was adopted (Tables S1,S2).

\section{Grading the quality of evidence}

The Grades of Recommendation, Assessment, Development and Evaluation (GRADE) criteria was applied to assess quality of evidence for each outcome.

The quality of evidence for outcomes on forced vital capacity (FVC)\% predicted, diffusing capacity of the lung for carbon monoxide (DLCO)\% predicted and change in FVC was judged as low due to serious risk of bias, which was upgraded because all plausible confounding would reduce demonstrated effect. The quality of evidence for outcome on six-minute walking distance $(6 \mathrm{MWD})$ was judged as very low due to serious risk of bias and serious imprecision, which was upgraded because all plausible confounding would reduce demonstrated effect.

\section{How results can be interpreted given the quality of the included studies?}

Taken together, the majority of included studies was observational studies with relatively higher risk of bias than RCTs, although we excluded several observational studies with high risk of bias (assessed a score of $\leq 5$ using the Newcastle-Ottawa Scale) in the meta-analysis. We applied the GRADE criteria to evaluate quality of each evidence, which revealed low quality of the primary results. Therefore, our confidence in the evidence was limited and these findings should be interpretated with caution. However, given limited synthetic analysis on anti-reflux therapy for idiopathic pulmonary fibrosis (IPF) currently, this study could provide a preliminarily systematic review with regard to anti-reflux therapy on pulmonary function in IPF. Additionally, several suggestions for future research were also proposed.

Table S1 Quality assessment for RCTs

\begin{tabular}{|c|c|c|c|c|c|c|c|}
\hline Study & $\begin{array}{l}\text { Random sequence } \\
\text { generation? } \\
\text { (selection bias) }\end{array}$ & $\begin{array}{c}\text { Allocation } \\
\text { concealment? } \\
\text { (selection bias) }\end{array}$ & $\begin{array}{l}\text { Blinding of participants, } \\
\text { personnel, and outcome } \\
\text { assessors? (performance } \\
\text { and detection bias) }\end{array}$ & $\begin{array}{l}\text { Incomplete } \\
\text { outcome data? } \\
\text { (attrition bias) }\end{array}$ & $\begin{array}{l}\text { Selective } \\
\text { reporting? } \\
\text { (reporting bias) }\end{array}$ & $\begin{array}{l}\text { Other } \\
\text { bias? }\end{array}$ & $\begin{array}{l}\text { Overall } \\
\text { risk of } \\
\text { bias }\end{array}$ \\
\hline Dutta 2019, (23) & Yes & Yes & Yes & No & No & No & Low \\
\hline Raghu 2018*, (45) & Yes & Yes & No & No & No & No & Low \\
\hline
\end{tabular}

Risk of bias was assessed using the Cochrane risk of bias tool. *, this RCT was unblinded for participants, personnel, and outcome assessors because the intervention in this RCT was surgery, which was difficult to reach blinding of participants. Meanwhile, the primary outcome, change in FVC, was measured in accordance with ATS/ERS standards. Therefore, the assessed overall risk of bias for this study was also low. RCT, randomized controlled trial; ATS, American Thoracic Society; ERS, European Respiratory Society. 
Table S2 Quality assessment for observational studies

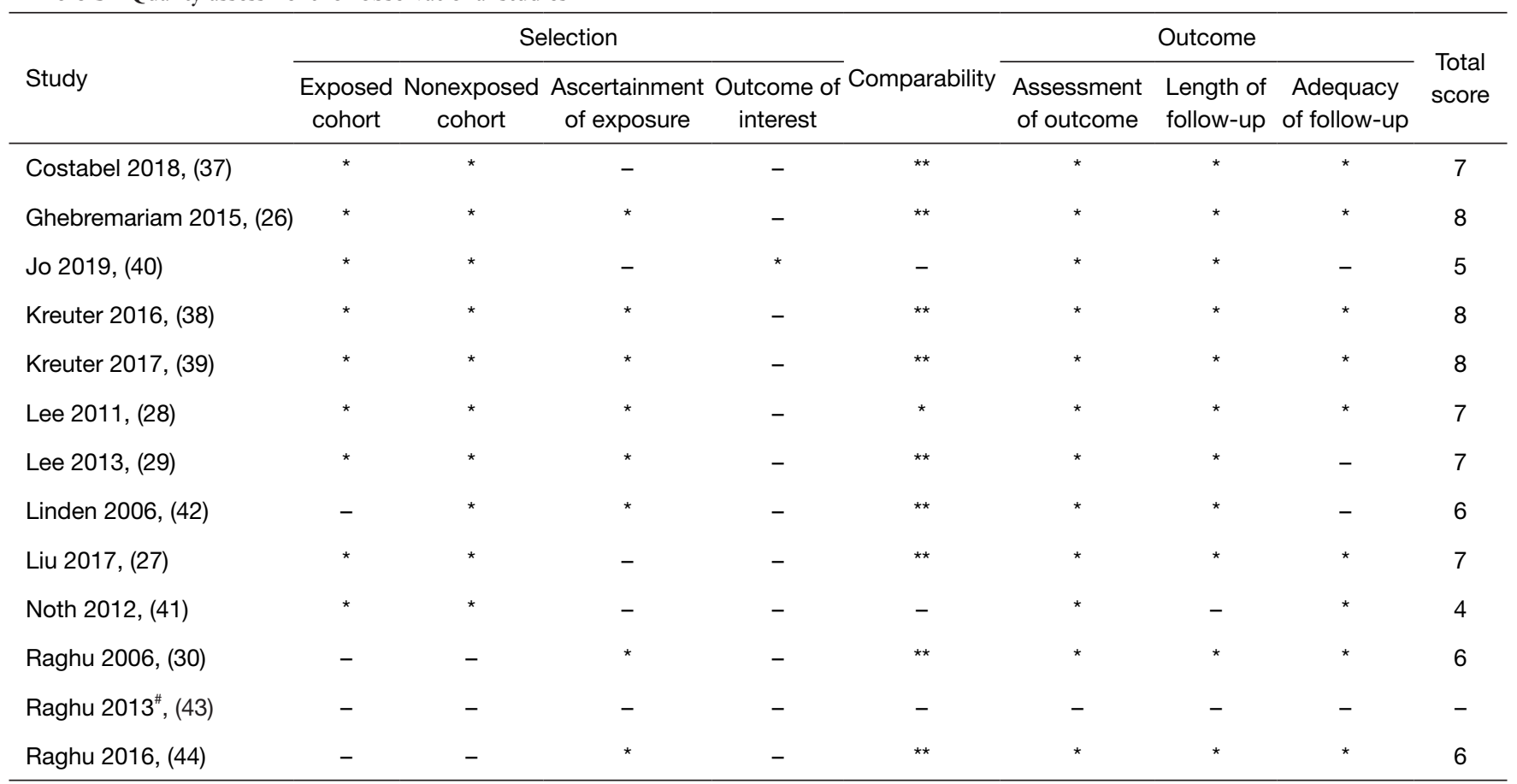

Risk of bias was assessed using the Newcastle-Ottawa Scale. A higher overall score corresponds to a lower risk of bias; a score of $\leq 5$ (out of 9) indicates a high risk of bias. ", this study was not assessed because it was published in abstract form without reporting detailed information. 